\title{
ANALISIS KUALITAS LAYANAN SISTEM INFORMASI OPEN BIBLIO MENGGUNAKAN METODE LIBQUAL+
}

\author{
(Studi Kasus: Perpustakaan UIN SUSKA Riau)
}

\author{
${ }^{1}$ Megawati, ${ }^{2}$ Dafit Syahputra \\ ${ }^{1,2}$ Program Studi Sistem Informasi Fakultas Sains dan Teknologi UIN Sultan Syarif Kasim Riau \\ Jl. HR. Soebrantas KM. 18.5 No. 155 Pekanbaru Riau 28293 \\ E-mail: ${ }^{1} \underline{\text { megawati@uin-suska.ac.id, } 2 \text { dafit201@gmail.com, }}$
}

\begin{abstract}
ABSTRAK
Sistem Informasi Open Biblio berperan sangat penting dalam otomasi Perpustakaan UIN SUSKA Riau guna meningkatkan kualitas layanan kepada pengunjung. Layanan dari sistem Open Biblio yang digunakan oleh pengunjung Perpustakaan UIN SUSKA Riau yaitu OPAC (Online Public Access Catalog) dan Sirkulasi. Akan tetapi masih ditemukan beberapa kendala terkait layanan sistem Open Biblio di Pepustakaan UIN SUSKA Riau, seperti ketidak akuratan data pada OPAC, informasi koleksi kurang update dan kurangnya fasilitas komputer sehingga mengahambat pengunjung untuk melakukan akses informasi. Tujuan dari penelitian ini adalah untuk mengetahui kualitas layanan sistem informasi Open Biblio di Perpustakaan UIN SUSKA Riau berdasarkan kepuasan pengguna. Analisis dilakukan dengan menggunakan metode LibQUAL+ dengan indikator Affect of Service, Information dan Library as Place. Berdasarkan analisis skor Adequacy Gap (AG) menunjukkan skor positif 0.32, berarti bahwa layanan yang diberikan telah memenuhi harapan minimum pengunjung "cukup puas" terhadap layanan yang diterimanya. Sedangkan skor Superiority Gap (SG) menunjukkan skor negatif -1,42, berarti menunjukkan bahwa kualitas layanan sistem informasi Open Biblio dinilai "baik", berada pada "batas toleransi / zone of tolerance", dimana kualitas layanan berada diantara tingkat harapan minimum dan harapan ideal (desired).
\end{abstract}

Kata Kunci: Sistem Informasi, Open Biblio, User Satisfaction, LibQUAL+

\section{A. PENDAHULUAN}

Perpustakaan UIN Sultan Syarif Kasim (SUSKA) Riau adalah jantung universitas dan sumber khasanah literatur melayu Islam. Perpustakaan UIN SUSKA Riau merupakan pusat perpustakaan UIN SUSKA Riau yang menyimpan ribuan macam koleksi di dalamnya. Perpustakaan UIN SUSKA Riau menerapkan sebuah sistem informasi yang bernama Open Biblio guna meningkatkan kualitas pelayanan perpustakaan kepada pengunjung.

Adapun layanan dari sistem Open Bibilio yang digunakan oleh pengunjung di perpustakaan UIN SUSKA Riau, yaitu OPAC (Online Public Access Catalog) dan Sirkulasi. Berdasarkan hasil observasi dan wawancara kepada pengunjung yang menggunakan layanan sistem Open Biblio di Perpustakaan UIN SUSKA Riau ditemukan beberapa kendala diantaranya:

1. Adanya data koleksi yang tidak akurat pada layanan OPAC (Online Public Access Catalog) dengan data koleksi yang ada pada jajaran rak, akibatnya pengunjung sulit menemukan koleksi yang mereka butuhkan.

2. Informasi koleksi yang tersedia kurang update, sehingga pengunjung tidak mendapatkan koleksi terbaru.
3. Kurangnya fasilitas komputer sehingga membuat terhambatnya akses informasi bagi pengunjung.

Berdasarakan permasalahan tersebut tentu membuat layanan sistem informasi Open Biblio kepada pengunjung Perpustakaan UIN SUSKA Riau menjadi terhambat dan kurang maksimal. Oleh karena itu perlu dilakukan pengukuran agar dapat memberikan gambaran serta memberikan masukan dalam memprediksi dan memperbaiki kualitas layanan sistem informasi Open Biblio di Perpustakaan UIN SUSKA Riau. Dalam melakukan pengukuran ini diperlukan metode yang tepat sesuai dengan latar belakang permsalahan. Adapun metode yang tepat dalam melakukan analisis atau pengukuran kualitas layanan sistem Open Biblio ini yaitu metode LibQUAL+. Metode LibQUAL+ merupakan metode khusus yang dikembangkan untuk mengukur kualitas layanan perpustakaan berdasarkan persepsi pengunjung atau pengguna.

Adapun tujuan dari dilakukannya penelitian ini yaitu:

1. Untuk mengetahui kualitas layanan sistem informasi Open Biblio berdsarkan kepuasan pengunjung yang menggunakan layanan sistem Open Biblio di Perpustakaan UIN SUSKA Riau. 
2. Untuk mengetahui variabel pernyataan dari metode LibQUAL+, yang perlu diperbaiki guna meningkatkan kualitas layanan sistem informasi Open Biblio di Perpustakaan UIN SUSKA Riau kepada pengunjung.

\section{B. BAHAN DAN METODE \\ B.1 Sistem Informasi}

Sistem Informasi (SI) adalah kombinasi dari teknologi informasi dan aktivitas orang yang menggunakan teknologi itu untuk mendukung operasi dan manajemen. Dalam arti yang sangat luas, istilah sistem informasi yang sering digunakan merujuk kepada interaksi antara orang, proses algoritmik, data, dan teknologi. Dalam pengertian ini, istilah ini digunakan untuk merujuk tidak hanya pada penggunaan organisasi teknologi informasi dan komunikasi (TIK), tetapi juga untuk cara di mana orang berinteraksi dengan teknologi ini dalam mendukung proses bisnis [1].

\section{B.2 Open Biblio}

Open Biblio merupakan perangkat lunak otomasi perpustakaan berbasis web. Software ini merupakan hasil karya dari Dave Stevans. Open Biblio menyediakan menu Online Public Access Catalog (OPAC), sirkulasi (circulation), katalogisasi (cataloging), laporan (report), serta menu admin (administration). Berbagai menu-menu tersebut terintegrasi dalam sistem yang dibangun oleh software ini, sehingga satu menu akan berpengaruh terhadap menu yang lain. Open Biblio dibangun dengan menggunakan PHP sebagai bahasa pemrograman, MySQL sebagai database dan program web server sebagai Apache atau Xitami. Open Biblio juga mampu berjalan di dua sistem operasi yaitu Linux dan Windows. Karena program ini mampu berjalan di dua sistem operasi maka tidak akan menimbulkan masalah bagi perpustakaan yang menggunakan sistem operasi windows atau linux [2].

\section{B.3 User Satisfaction}

Kepuasan pengguna komputer adalah sikap pengguna ke sistem komputer. Definisi Doll dan Torkzadeh (1988) tentang kepuasan pengguna adalah, pendapat pengguna tentang aplikasi komputer tertentu, yang mereka gunakan. Dalam arti yang lebih luas, definisi kepuasan pengguna dapat diartikan sebagai tingkat perasaan seseorang setelah membandingkan kinerja atau hasil yang ia rasakan dibandingkan dengan harapannya [3].

\section{B.4 LibQUAL+}

LibQUAL+ merupakan suatu rangkaian ,alate (metode) yang digunakan oleh perpustakaan untuk mengumpulkan, mencari, memahami dan menanggapi opini pemustaka terhadap kualitas pelayanan yang diberikan. Metode LibQUAL+ diperkenalkan oleh Association of Research Libraries (ARL), bekerja sama dengan Texas A\&M University sejak tahun 1999 [4].

Fatmawati dalam buku "Mengukur Kepuasan Pemustaka Menggunakan Metode LibQUAL+" menyatakan bahwa pengukuran kepuasan pemustaka menggunakan metode LibQUAL + menggunakan rumus berikut: [4]

1. AG (Adequacy Gap) = Persepsi (P) Harapan Minimum (HM). AG (Adequacy Gap) merupakan nilai selisih yang di peroleh dari persepsi $(\mathrm{P})$ dikurangi dengan harapan minimum (HM). Jadi AG akan bernilai positif, yang berarti responden "cukup puas" adalah jika persepsi > dari harapan minimum (P > HM).

2. SG (Superiority Gap) merupakan nilai selisih yang diperoleh dari persepsi (P) dikurangi dengan harapan ideal (HI). Nilai SG akan negatif, yang berarti "dalam batas toleransi (Zone of Tolerance) adalah jika persepsi < harapan ideal $(\mathrm{P}<\mathrm{HI})$. Rumus untuk menghitung nilai $A G$ adalah $S G$ $($ Superiority Gap $)=$ Persepsi $(\mathrm{P})-$ Harapan Ideal (HI).

3. Zone of Tolerance, merupakan suatu wilayah (area) antara tingkat minimum (HM) yang bisa diterima dan tingkat harapan ideal. Boykim menyampaikan bahwa "zone of tolerance" adalah "the area between minimally acceptable and desired service quality ratings". Maksudnya adalah area atau daerah yang letaknya antara minimum layanan yagn diterima sampai pada tingkat layanan yang diharapkan dari kualitas layanan yang diinginkan.

\section{HASIL DAN PEMBAHASAN}

Angket yang disebar berisi 20 pernyataan yang diambil dari setiap indikator dari dimensi metode LibQUAL+ yang digunakan, yaitu Affect of Service, Information Control, dan Library as Place. Jenis instrumen pada penelitian ini adalah menggunakan skala Likert, yaitu dengan tingkat jawaban terdiri dari 4 tingkatan.

\section{C.1 Karakteristik Responden}

C.1.1Karakteristik Responden Berdasarkan Jenis Kelamin

Karakteristik responden berdasarkan jenis kelamin yaitu Pria dan Wanita. Adapun karakteristik responden berdasarkan jenis kelamin dapat dilihat pada tabel berikut ini: 
Tabel 1. Karakteristik Responden Berdasarkan Jenis Kelamin

\begin{tabular}{lcc}
\hline Jenis Kelamin & Frekuensi & Presentase \\
\hline Pria & 30 & $30 \%$ \\
Wanita & 70 & $70 \%$ \\
Jumlah & 100 & $100 \%$ \\
\hline
\end{tabular}

Dari Tabel 4.1 di atas dapat diketahui bahwa jumlah responden wanita lebih banyak dari pada pria dengan jumlah responden wanita yaitu 70 orang dan jumlah responden pria 30 orang. Adapun presentase dari responden wanita yaitu $70 \%$ dan presntase dari responden pria $30 \%$.

C.1.2Karakteristik Responden Berdasarkan Fakultas

Karakteristik responden berdasarkan fakultas yaitu meliputi, Fakultas Tarbiyah dan Keguruan, Fakultas Syariah dan Ilmu Hukum, Fakultas Sains dan Teknologi, Fakultas Ushuluddin, Fakultas Dakwah dan Ilmu Komunikasi, Fakultas Ekonomi dan Ilmu Sosial, Fakultas Pertanian dan Peternakan. Adapun karakteristik responden berdasarkan fakultas dapat dilihat pada tabel berikut ini:

Tabel 2. Karakteristik Responden Berdasarkan Fakultas

\begin{tabular}{lcc}
\hline \multicolumn{1}{c}{ Fakultas } & Frekuensi & Presentase \\
\hline $\begin{array}{l}\text { Tarbiyah dan } \\
\text { Keguruan } \\
\text { Sains dan }\end{array}$ & 22 & $22 \%$ \\
Teknologi & 24 & $24 \%$ \\
$\begin{array}{l}\text { Ekonomi dan } \\
\text { Ilmu Sosial }\end{array}$ & 13 & $13 \%$ \\
$\begin{array}{l}\text { Syariah dan } \\
\text { Ilmu Hukum }\end{array}$ & 14 & $14 \%$ \\
$\begin{array}{l}\text { Dakwah dan } \\
\text { Ilmu }\end{array}$ & 11 & $11 \%$ \\
$\begin{array}{l}\text { Komunikasi } \\
\text { Ushuluddin }\end{array}$ & 15 & $15 \%$ \\
Pertanian dan & 1 & $1 \%$ \\
Peternakan & & \\
\hline
\end{tabular}

Dari Tabel 4.2 di atas dapat diketahui bahwa data karakteristik responden berdasarkan fakultas yang memiliki frekuensi paling tinggi yaitu pada Fakultas Sains dan Teknologi dengan frekuensi 24 orang dengan presentase $24 \%$, sedangkan yang memiliki frekuensi paling rendah berada pada Fakultas Pertanian dan Peternakan dengan jumlah frekuensi 1 orang dengan presentase 1\%. Adapun untuk Fakultas Tarbiyah dan Keguruan memilki frekuensi 22 orang dengan presentase 22\%, Fakultas Ushuluddin 15 orang dengan presentase 15\%, Fakultas Syariah dan Ilmu Hukum 14 orang dengan presentase 14\%, Fakultas ekonomi dan Ilmu Sosial 13 orang dengan presentase 13\%, Fakultas Dakwah dan Ilmu Komunikasi 11 orang dengan presentase $11 \%$.

C.1.3Karakteristik Responden Berdasarkan Semester

Karakteristik responden berdsarkan semester yaitu meliputi, Semeser Dua (II), Semester Empat (IV), Semester Enam (VI), Semester Delapan (VIII), Semester Sepuluh (X), Semeter Dua Belas (XII), Semester Empat Belas (X1V). Adapun karakteristik responden berdasarkan semester dapat dilihat pada tabel berikut:

Tabel 3.Karakteristik Responden Berdasarkan Semester

\begin{tabular}{ccc}
\hline Semester & Frekuensi & $\begin{array}{c}\text { Presenta } \\
\text { se }\end{array}$ \\
\hline II & 17 & $17 \%$ \\
IV & 17 & $17 \%$ \\
VI & 18 & $18 \%$ \\
VIII & 30 & $30 \%$ \\
X & 12 & $12 \%$ \\
XII & 3 & $3 \%$ \\
XIV & 2 & $2 \%$ \\
\hline
\end{tabular}

Berdasarkan Tabel 4.3 di atas dapat diketahui bahwa data responden berdasarakan semester yang memiliki ferekuensi paling tinggi yaitu pada semester VIII dengan ferekuensi 30 orang dengan presentase $30 \%$, sedangkan yang memiliki frekuensi paling rendah berada pada semester XIV dengan frekunsi 2 orang dengan presentase $2 \%$. Adapun untuk semester VI memiliki frekuensi 18 orang dengan presentase $18 \%$, semester II dan IV memiliki nilai frekuensi yang sama yaitu 17 orang dengan presentase yang sama $17 \%$, semester $\mathrm{X}$ memiliki frekuensi 12 orang dengan presentase $12 \%$, semester XII memiliki frekunsi 3 orang dengan presentase $3 \%$.

\section{C.2 Perhitungan LibQUAL+}

C.2.1Nilai LibQUAL+ Perdimensi

Setelah kuesioner terkumpul dilakukan perhitungan dengan Microsoft Exell 2010 dan memenuhi syarat jumlah sampel minimum seta melakukan uji validitas dan reliabilias langkah selanjutnya yaitu:

1. Data mentah dari kuesioner diolah menjadi data LibQUAL+ dengan merata-ratakan penilaian responden untuk masing-masing kategori kuesioner persepsi, kuesioner harapan minimum, dan kuesioner harapan ideal.

2. Menentukan nilai rata-rata perdimensi tiap kuesioner dengan menjumlahkan pernyataan yang sama berdasarkan banyaknya responden dan dibagi dengan banyaknya responden. 
Jurnal Ilmiah Rekayasa dan Manajemen Sistem Informasi, Vol. 6, No. 1, Februari 2020, Hal. 93-99 e-ISSN 2502-8995 p-ISSN 2460-8181

Tabel 4. Rekapitulasi Nilai LibQUAL+ Perdimensi

\begin{tabular}{|c|c|c|c|}
\hline $\begin{array}{c}\text { Dimensi } \\
\text { LibQUAL } \\
+\end{array}$ & $\begin{array}{c}\text { Rata- } \\
\text { Rata } \\
\text { Persepsi }\end{array}$ & $\begin{array}{c}\text { Rata-Rata } \\
\text { Harapan } \\
\text { Minimum }\end{array}$ & $\begin{array}{c}\text { Rata-Rata } \\
\text { Harapan } \\
\text { Ideal }\end{array}$ \\
\hline $\mathrm{AS}$ & 3,34 & 3,13 & 3,64 \\
\hline IC & 3,21 & 3,20 & 3,73 \\
\hline LP & 3,22 & 3,12 & 3,82 \\
\hline
\end{tabular}

Setelah didapatkan nilai dari rata-rata persepsi, harapan minimum dan harapan ideal, maka dilakukan perhitungan GAP perdimensi dengan menggunakan perhitungan Adequacy Gap dan Superiority Gap sehingga diperoleh hasil pada table berikut ini:

Tabel 5. Nilai Kesenjangan AG dan SG perdimensi

\begin{tabular}{lccccc}
\hline $\begin{array}{c}\text { Dimensi } \\
\text { LibQUA } \\
\text { L }+\end{array}$ & $\begin{array}{c}\text { Rata- } \\
\text { rata } \\
(\mathbf{P})\end{array}$ & $\begin{array}{c}\text { Rata- } \\
\text { rata } \\
(\mathbf{H M})\end{array}$ & $\begin{array}{c}\text { Rata- } \\
\text { rata } \\
(\mathbf{H I})\end{array}$ & AG & SG \\
\hline $\begin{array}{l}\text { Affect of } \\
\text { Service }\end{array}$ & 3,34 & 3,13 & 3,64 & 0,21 & $-0,30$ \\
$\begin{array}{l}\text { Informati } \\
\text { on }\end{array}$ & 3,21 & 3,20 & 3,73 & 0,01 & $-0,52$ \\
$\begin{array}{l}\text { Control } \\
\text { Library } \\
\text { as Place }\end{array}$ & 3,22 & 3,12 & 3,82 & 0,1 & $-0,06$ \\
Total & 9,77 & 9,45 & 11,19 & 0,32 & $-1,42$ \\
\hline
\end{tabular}

Berdasarkan Tabel 5 di atas diperoleh total keseluruhan analisis skor Adequacy Gap (AG) menunjukkan skor positif yaitu 0,32 berarti bahwa layanan yang diberikan telah melebihi harapan minimum pengunjung Perpustakaan, jadi pengunjung "cukup puas" terhadap layanan OPAC yang ada. Analisis skor Superiority Gap (SG) menunjukkan skor negatif yaitu -1,42, berarti, menunjukkan bahwa kualitas layanan dinilai "baik", berada dalam batas toleransi, dimana kualitas layanan berada diantara tingkat minimum yang dapat diterima.

\section{C.2.2 Perhitungan Adequacy Gap (AG)}

AG merupakan nilai selisih yang di peroleh dari persepsi (P) dikurangi dengan harapan minimum (HM). Jadi AG akan bernilai positif, yang berarti responden "cukup puas" adalah jika persepsi $>$ dari harapan minimum $(\mathrm{P}>\mathrm{HM})$. Rumus untuk mencari AG adalah AG (Adequacy Gap) = Persepsi $(\mathrm{P})-$ Harapan Minimum (HM).

1. Dimensi Affect of Service

$\mathrm{AG}=$ Persepsi $(\mathrm{P})-$ Harapan Minimum (HM)

$$
\begin{aligned}
& =3,34-3,13 \\
& =0,21
\end{aligned}
$$

2. Dimensi Information Control
$\mathrm{AG}=$ Persepsi $(\mathrm{P})-$ Harapan Minimum

(HM)

$=3,21-3,2$

$=0,01$

3. Dimensi Library as Place

$\mathrm{AG}=$ Persepsi $(\mathrm{P})$ - Harapan Minimum

(HM)

$=3,22-3,12$

$=0,1$

C.2.3 Perhitungan Superiority Gap (SG)

SG merupakan nilai selisih yang diperoleh dari persepsi (P) dikurangi dengan harapan ideal (HI). Nilai SG akan negatif, yang berarti "dalam batas toleransi (Zone of Tolerance) adalah jika persepsi < harapan ideal $(\mathrm{P}<\mathrm{HI})$. Rumus untuk menghitung nilai $\mathrm{SG}$ adalah $\mathrm{SG}=$ Persepsi $(\mathrm{P})-$ Harapan Ideal (HI).

1. Dimensi Affect of Service

$\mathrm{SG}=$ Persepsi $(\mathrm{P})$ - Harapan Ideal $(\mathrm{HI})$

$=3,34-3,64$

$=-0,30$

2. Dimensi Information Control

$\mathrm{SG}=$ Persepsi $(\mathrm{P})-$ Harapan Ideal $(\mathrm{HI})$

$=3,21-3,73$

$=-0,52$

3. Dimensi Library as Place

$\mathrm{SG}=$ Persepsi $(\mathrm{P})-$ Harapan Ideal $(\mathrm{HI})$

$=3,22-3,82$

$=-0,6$

Untuk lebih jelas melihat hasil perhitungan dari Adequacy Gap (AG) dan Superiority Gap (SG) dapat dilihat pada tabel berikut:

Tabel 6. Rekapitulasi Nilai Kesenjangan AG dan SG Perdimensi LibQUAL+

\begin{tabular}{llllll}
\hline $\begin{array}{l}\text { Dimensi } \\
\text { LibQUAL+ }\end{array}$ & $\begin{array}{l}\text { Rata- } \\
\text { rata } \\
\text { (P) }\end{array}$ & $\begin{array}{l}\text { Rata- } \\
\text { rata } \\
\text { (HM) }\end{array}$ & $\begin{array}{l}\text { Rata- } \\
\text { rata } \\
(\mathbf{H I})\end{array}$ & AG & SG \\
\hline $\begin{array}{l}\text { Affect of } \\
\text { Service }\end{array}$ & 3,34 & 3,13 & 3,64 & 0,21 & $-0,30$ \\
$\begin{array}{l}\text { Information } \\
\text { Control }\end{array}$ & 3,21 & 3,20 & 3,73 & 0,01 & - \\
$\begin{array}{l}\text { Library as } \\
\text { Place }\end{array}$ & 3,22 & 3,12 & 3,82 & 0,1 & $-0,6$ \\
Jumlah & 9,77 & 9,45 & 11,19 & 0,32 & $-1,42$ \\
\end{tabular}

Dari Tabel 6 dapat dilihat nilai kesenjangan Adequacy Gap (AG) yang paling besar yaitu pada dimensi Affect of Service yaitu sebesar 0,21 sedangkan untuk kesenjangan Superiority Gap (SG) paling besar pada dimensi Information Control yaitu sebesar -0,52. Hal ini berarti harapan pengguna yang 
meliputi tentang akses dan kontrol informasi pada sistem Open Biblio di perpustakaan lebih besar dari kenyataan yang diterima selama ini.

Dari total keseluruhan analisis skor Adequacy Gap menunjukkan skor positif yaitu 0,32 , berarti bahwa layanan yang diberikan telah melebihi harapan minimum pengunjung perpustakaan, jadi pengunjung "cukup puas" terhadap layanan sistem yang ada. Adapun analisis skor Superiority Gap (SG) menunjukkan skor negatif yaitu $-1,42$, menunjukkan bahwa kualitas layanan sistem informasi Open Biblio dinilai "baik", berada dalam batas toleransi, dimana kualitas layanan berada diantara tingkat minimum yang dapat diterima.

Tabel 7. Identifikasi Gap dengan Dimensi LibQUAL+

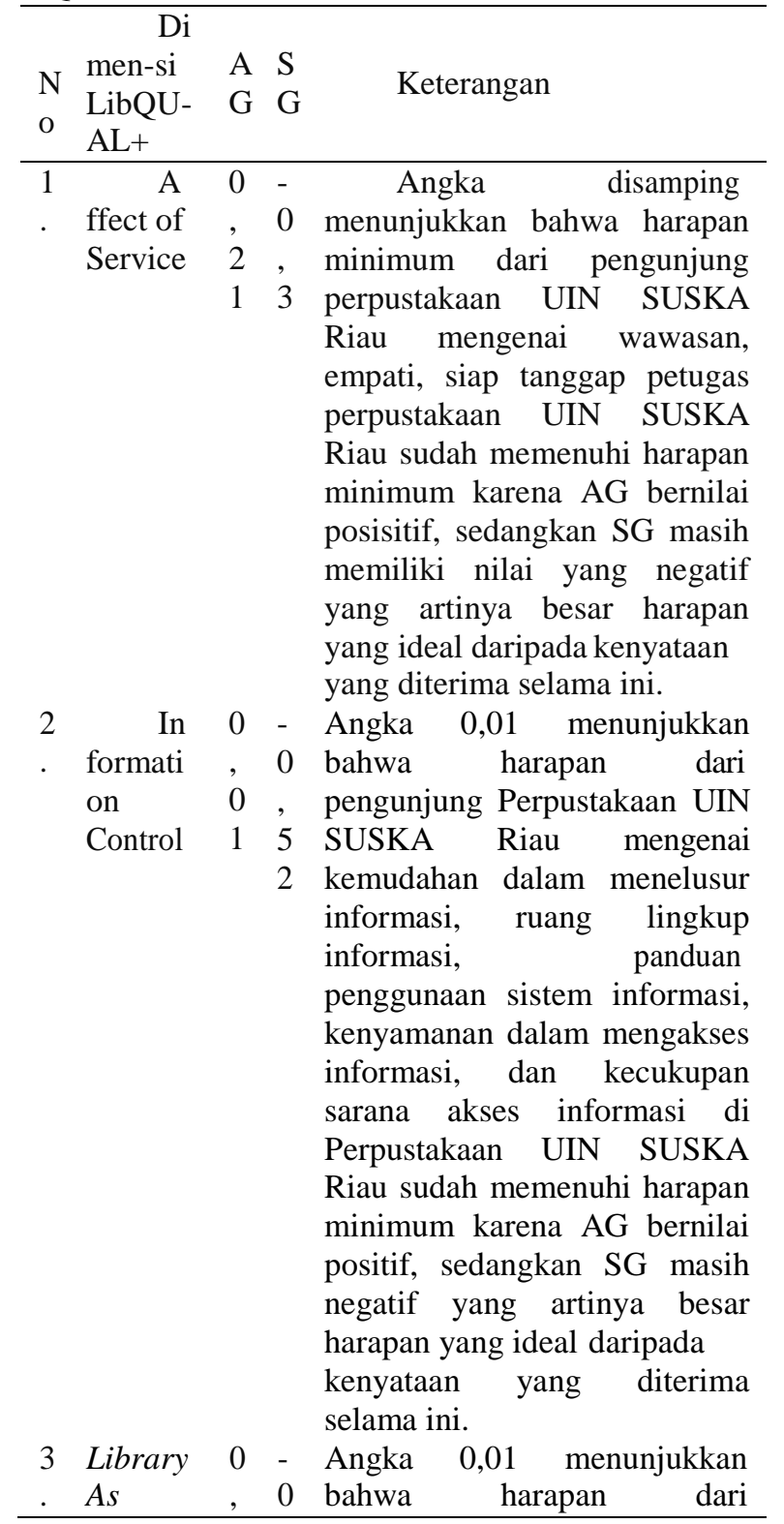

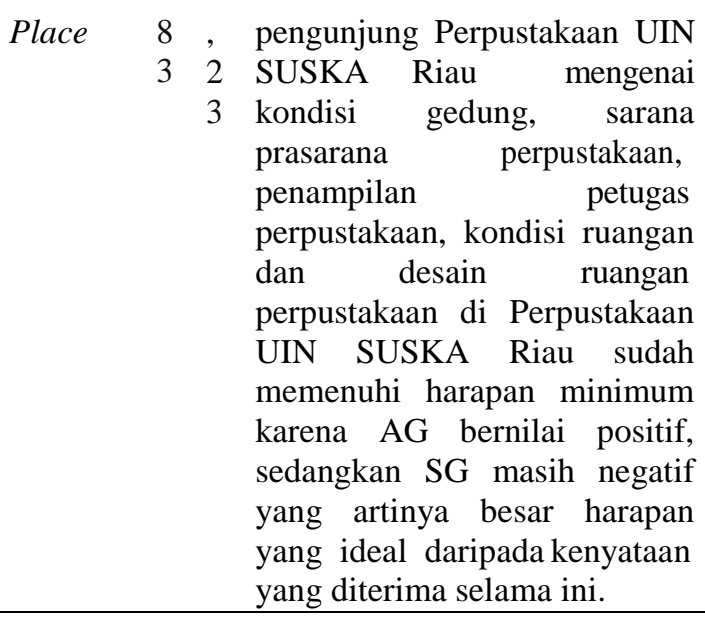

C.3 Nilai LibQUAL+ Masing-masing Pernyataan Untuk melihat hasil Adequacy Gap (AG) dan Superirity Gap (SG) yang lebih jelas maka dilakukan perhitungan LibQUAL+ pervariabel seperti pada tabel dibawah ini :

Tabel 6. Perhitungan kesenjangan AG dan SG masingmasing pernyataan

\begin{tabular}{lccccc}
\hline $\begin{array}{c}\text { Pernya- } \\
\text { taan }\end{array}$ & $\mathbf{P}$ & $\mathbf{( H M )}$ & $(\mathbf{H I})$ & $\mathbf{A G}$ & $\mathbf{S G}$ \\
\hline AS1 & 3,49 & 3,08 & 3,66 & 0,41 & $-0,17$ \\
AS2 & 2,88 & 3,24 & 3,65 & $-0,36$ & $-1,77$ \\
AS3 & 3,49 & 3,10 & 3,61 & 0,39 & $-0,12$ \\
AS4 & 3,50 & 3,11 & 3,65 & 0,39 & $-0,15$ \\
IC1 & 3,36 & 3,16 & 3,73 & 0,20 & $-0,37$ \\
IC2 & 3,00 & 3,19 & 3,78 & $-0,19$ & $-0,78$ \\
IC3 & 3,33 & 3,16 & 3,76 & 0,17 & $-0,43$ \\
IC4 & 3,34 & 3,08 & 3,72 & 0,26 & $-0,38$ \\
IC5 & 3,35 & 3,16 & 3,73 & 0,19 & $-0,38$ \\
IC6 & 3,34 & 3,08 & 3,72 & 0,26 & $-0,38$ \\
IC7 & 3,29 & 3,17 & 3,77 & 0,12 & $-0,48$ \\
IC8 & 2,96 & 3,13 & 3,77 & $-0,17$ & $-0,81$ \\
IC9 & 3,51 & 3,30 & 3,74 & 0,21 & $-0,41$ \\
IC10 & 2,86 & 3,18 & 3,65 & $-0,32$ & $-0,79$ \\
LP1 & 3,29 & 3,14 & 3,77 & 0,15 & $-0,48$ \\
LP2 & 3,29 & 3,19 & 3,81 & 0,10 & $-0,52$ \\
LP3 & 3,35 & 3,11 & 3,83 & 0,24 & $-0,48$ \\
LP4 & 2,89 & 3,10 & 3,84 & $-0,21$ & $-0,95$ \\
LP5 & 3,20 & 3,12 & 3,82 & 0,08 & $-0,62$ \\
LP6 & 3,32 & 3,17 & 3,86 & 0,15 & $-0,54$ \\
\hline
\end{tabular}

C.4 Analisis Adequacy Gap (AG) 
Untuk melihat kesenjangan antara persepsi dengan harapan minimum maka digambarkan dalam bentuk diagram radar seperti gambar berikut:

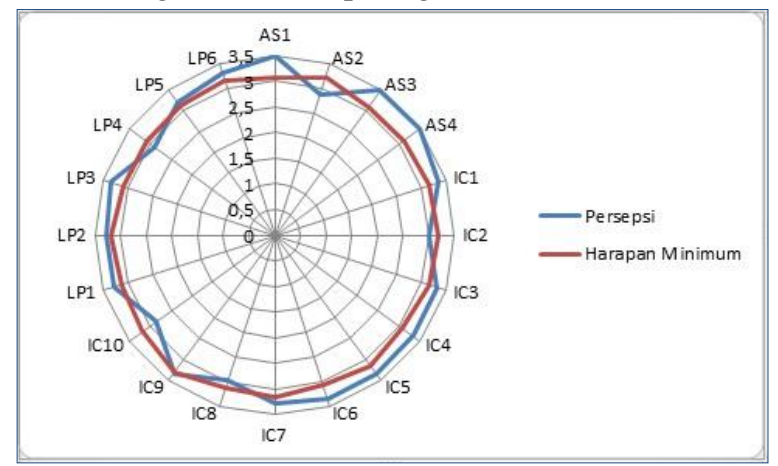

Gambar 2. Diagram Radar Kesenjangan

Persepsi dan Harapan Minimum

Berdasarkan Gambar 2 pada diagram Radar di atas dapat diketahui nilai kesenjangan AG paling besar yaitu AS1, AS3, AS4 dan paling rendah bernilai negatif pada AS2, IC10, LP4.

\section{C.5 Analisis Superiority Gap (SG)}

Untuk melihat kesenjangan antara persepsi dengan harapan ideal maka digambarkan dalam bentuk diagram radar seperti gambar berikut :

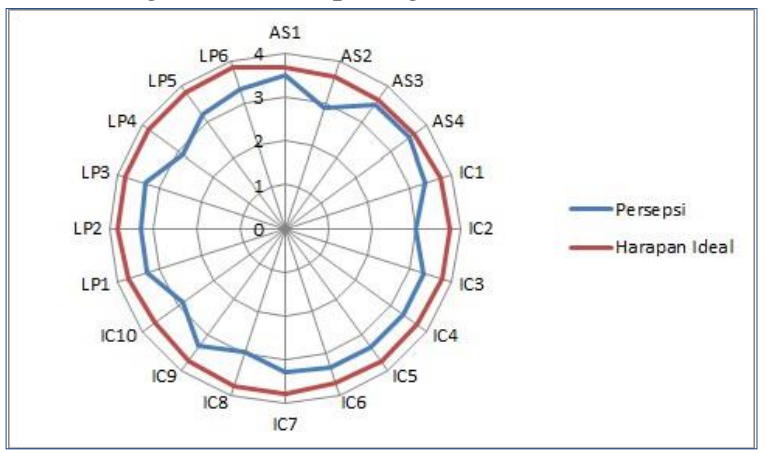

Gambar 3. Diagram Radar Kesenjangan Pressepsi dan Harapan Ideal

Dari gambar II dapat dilihat nilai persepsi lebih rendah dari pada harapan maksimum.Sehingga dapat dilihat kesenjangan paling besar antara persepsi dan harapan ideal terdapat pada AS2, LP4, IC8, IC10, IC2. Jadi, secara keseluruhan harapan yang sangat diidealkan atau diharapkan pengunjung terpenuhi yaitu pada dimensi Information Control.

\section{PENUTUP}

Dari hasil analisis dan pembahasan yang telah dilakukan mengenai kepuasan pengguna terhadap layanan sistem Open Biblio di Perpustakaan UIN SUSKA Riau maka, dapat diambil kesimpulan sebagai berikut:
1. Kualitas layanan sistem informasi Open Biblio di perpustakaan UIN SUSKA Riau dinilai sudah memenuhi kualitas yang baik, hal ini berdasarkan analisis Skor Adequacy Gap (AG) yang menunjukkan skor positif 0,32 berarti bahwa layanan yang diberikan telah melebihi harapan minimum pengunjung. Sedangkan skor Superiority Gap (SG) menunjukkan skor negative -1,42, berarti menunjukkan bahwa kualitas layanan sistem informasi Open Biblio berada diantara tingkat minimum yang dapat diterima. Namun masih terdapat kesenjangan pada masing-masing pernyataan.

2. Dari hasil penelitian ini dapat diketahui layanan sistem informasi Open Biblio yang perlu diprioritaskan untuk diperbaiki yaitu layanan pada dimensi Information Control karena memiliki nilai Superiority Gap tertinggi yaitu IC8 -0,81 (data koleksi perpustakaan yang ditampilkan pada sistem informasi perpustakaan (OPAC) selalu akurat dengan data koleksi yang ada pada jajaran rak, sehingga saya dapat menemukan koleksi yang saya butuhkan dengan cepat), IC10 -0,79 (jumlah unit komputer sistem informasi perpustakaan sudah memadai, sehingga saya dapat dengan mudah melakukan akses informasi dan peminjaman koleksi di perpustakaan), IC2 $-0,78$ (informasi pada layanan OPAC selalu update).

Dari hasil penelitian yang telah dilakukan maka peneliti memberikan dua saran dalam penelitian ini antaralain:

1. Perpustakaan UIN SUSKA Riau perlu memperhatikan setiap layanan yang diberikan kepada penggunjung terutama pada layanan yang belum memberikan kepuasan kepada penggunjung perlu diprioritaskan untuk segera diperbaiki guna memperoleh tingkat kepuasan pengunjung yang maksimal.

2. Untuk penelitian selanjutnya agar dapat mengkaji semua layanan yang tersedia pada sistem Open Biblio perpustakaan UIN SUSKA Riau, tidak hanya dinilai dari sisi pengunjungnya saja tetapi juga dari sisi pustakawan atau pegawai perpustakaan yang juga menggunakan sistem Open Biblio di perpustakaan UIN Suka Riau.

\section{REFERENSI}

[1] Anggraeni, Elisabet Yunaeti. "Pengantar Sistem Informasi”. Penerbit Andi, 2017. 
Jurnal Ilmiah Rekayasa dan Manajemen Sistem Informasi, Vol. 6, No. 1, Februari 2020, Hal. 93-99 e-ISSN 2502-8995 p-ISSN 2460-8181

[2] www.lib.uin-suska.ac.id, diakses November 2019.

[3] Dalimunthe Nurmaini, Dewi. “Analisis Kualitas Layanan Sistem Informasi InlisLite Menggunakan Metode Libqual (Studi Kasus: Badan Perpustakaan dan Arsip Kota pekanbaru)". Vol.13, No.2, ISSN: 2407- 0939, Jurnal Sains, Teknologi dan Industri, Juni 2016.

[4] www.libqual.org, diakses November 2019

[5] Rahayuningsih, Franciska. "Mengukur Kepuasan Pemustaka menggunakan Metode Libqual”. Graha Ilmu,Yogyakarta. 2015. 